DOI 10.18551/rjoas.2021-10.02

\title{
THE EFFECT OF E-LEARNING AND LEARNING MOTIVATION ON ACADEMIC STRESS WITH SELF-EFFICACY AS A MEDIATION VARIABLE DURING THE COVID-19 PANDEMIC
}

\author{
Atiyah* $^{*}$ \\ Master's Program of Management Science, University of Sriwijaya, Palembang, Indonesia
}

Adam Mohamad, Zunaidah

Faculty of Economics, University of Sriwijaya, Palembang, Indonesia

*E-mail: atiyah.shahab@gmail.com

\begin{abstract}
This study aims to examine the effect of e-learning and learning motivation on academic stress with self-efficacy as a mediation variable during the covid-19 pandemic. The data collection technique used a proportional random sampling of 280 respondents who were divided into Junior High School at one of the Junior High School in South Sumatra, Indonesia. Data analysis used the Structural Equation Modeling (SEM-AMOS) method with AMOS-23 software. The novelty of this study combines the four variables of e-learning, learning motivation, self-efficacy and academic stress in one research variable. The results of this study indicate that the variables e-learning and learning motivation have a positive and significant direct effect on self-efficacy. E-learning has no effect on academic stress. Learning motivation have a direct and significant impact on academic stress; self-efficacy can significantly mediate the effect between e-learning and learning motivation for academic stress. The weakness of the research is the small number of samples and the possibility of high subjectivity in respondents' answers. Future research is suggested to broaden the scope of respondents.
\end{abstract}

\section{KEYWORDS}

E-learning, learning motivation, self-efficacy, academic stress.

The policy of moving learning activities from school to home has implications for changing the learning model, from face to face to online (Donovan et al., 1999). Online learning methods using the E-learning system need supporting tools such as mobile devices that can access the internet anytime and anywhere, such as Android phones, laptops, computers, and tablets (Grant \& Gikas, 2013). Online learning (E-learning) has flexibility that allows students to adapt to the obstacles faced during online learning both in terms of time and place (Petrides, 2002). Learning independently using the E-learning system is related to student learning motivation (Suryatna, 2017). Learning motivation is motivation or encouragement that makes someone interested in learning so that they can continue to learn (Rimbarizki, 2017). Student learning motivation is different, there are students who are more motivated to learn and there are also students who are less motivated to learn (Wulandari \& Surjono, 2013). In addition to learning motivation, student behavior in certain situations also depends on the relationship between the environment, behavior, and other cognitive states, especially when it comes to students' beliefs about the ability to behave themselves in order to achieve the desired goals achieved (Meiliati \& Darwis, 2018).

Bandura (1994) Self-efficacy refers to the actions needed by a person to increase motivation, cognitive abilities, and overcome various situations and beliefs that exist in individuals can help students in dealing with various situations they face. Higher self-efficacy will perform better in class, by showing various efforts and perseverance, and can effectively solve the problems encountered through the cognitive and emotional processes they experience. Students with low self-efficacy will realize their shortcomings and think that the situation is more complicated than it really is. In contrast, students who have high self- 
efficacy will feel motivated when facing challenges and believe that they are able to face the challenges or obstacles they face. This is in accordance with what was stated by Sarafino (2006) who said that individuals who have high self-efficacy will experience lower pressure when dealing with sources of stress or stressors. Academic pressure is the cause of stress in the learning process, such as pressure to get good grades, study time, number of assignments, low grades/achievements and anxiety facing exams (Barseli \& Ifdil, 2017). The causes of student academic pressure are mentality, personality, self-confidence, study time, peer pressure, demands for achievement and encouragement from parents.

\section{LITERATURE REVIEW}

Zhang \& Zhu (2017) E-learning is an online learning that is convenient to use both in terms of the model and the novelty of its form based on the latest technology that has a positive impact on modern learning, so that any form of media and learning equipment can support E-learning activities, including the use of e-learning, multimedia in learning. Elearning is defined as a type of learning and teaching that allows the delivery of material partially open to students using the internet, Intranet or other media from computer networks (Darin E. Hartley, 2001).

According to behaviorism theory, Cognitivism theory and Constructivism theory argue that behaviorists propose a well-organized deductive approach to designing online learning and focuses on cognitive psychology of receiving and processing learner information to transfer it into long-term memory for storage (Moedritscher, 2006). Experience and social relationships play a very important role in a learning process (Moedritscher, 2006).

Selye (1956) revealed the physiological and psychological adjustment of the body to the demands imposed either by oneself or by others that are considered burdensome to students. When the request received is not in accordance with the ability to cope with the request, stress is a state experienced by humans (Looker \& Gregson, 2005). Bao (2020) shows that the perception of "E-learning crack-ups" has an effect on students' psychological pressure, and the fear of missing the school year during the covid-19 pandemic.

McClelland (1975) defines learning motivation as motivation that encourages individuals to achieve success, and aims to succeed in competition or competition with some standard of excellence. According to Atkinson (1982) learning motivation is a person's tendency to pursue success and have a goal orientation, success or failure. Learning motivation is an encouragement from internal and external stimuli, so it is hoped that some behaviors or activities will change better than before (Hamzah B. Uno, 2017).

Various theories can be used in discussing learning motivation theory according to Wloskowski (2004) including attribution theory, Covington's self-worth, motivational expectation theory, goal achievement orientation theory, including the theory proposed by Hamzah B. Uno (2017) where learning motivation is divided into two groups, namely intrinsic motivation and extrinsic motivation.

Sarafino (2006) defines self-efficacy as a person's assessment of their ability to plan and carry out actions that lead to certain goals. Santrock (2007) defines self-efficacy as a belief and belief in one's ability to master and overcome situations and produce satisfactory results. This is according to Sarafino (2006) who says that when a person experiences stress or causes stress, the effect of high self-esteem will be less resistant to stress.

Chang \& Chiou (2017) In the publication of Social Foundations of Thought and Action: A Social Cognitive Theory, Bandura develops a view of human functioning. Self-efficacy known as social cognitive theory or social learning theory is a person's belief that he or she is capable of performing a particular task successfully. In Zega's research (2020) the results show that there is a relationship between self-efficacy and student learning motivation. The self-efficacy component of Bandura's social cognitive theory has had a profound impact on the study of motivation in academia, Bandura emphasized in his social cognitive theory the construct of self-efficacy and its impact on learning, because belief in one's own abilities can influence outcomes (Zimmerman, 2006). 
There are two categories of theories that focus on the specific relationship between external demands (stressors) and bodily processes (stress), namely approaches to systemic stress based on physiology and psychobiology (Selye, 1976) and approaches to psychological stress developed in the field of cognitive psychology (Lazarus 1966, 1991, Lazarus and Folkman 1984, McGrath 1982). Stress is basically a condition that can be experienced by everyone regardless of age, gender, race, and other aspects of life (Utami et al., 2020). Academic pressure refers to unpleasant psychological conditions (Sarita, 2015).

Bandura's opinion about reciprocal determinism that: (a) personal factors in the form of cognition, biological and affective events (b) behavior, (c) environmental influences that make the interaction into triadic reciprocality. This is in line with the research of Shadi, Peyman, Taghipour, \& Tehrani (2018) which shows that high levels of academic stress can cause disturbances in thought processes, perceptions and problem-solving abilities as well as sleep disturbances and reduced decision-making power.

Pottie \& Ingram (Dada et al., 2019) stress is a biological psychosocial system demand, which causes tension, anxiety, and requires additional energy both physically and psychologically. Environmental stimuli that cause stress or tension, whether physical, psychological or social, are all called stressors, and dealing with stress is called coping. Stress at school according to Selye (1956) in (Matheny, 193:110) refers to the physiological and psychological adjustment of the body to the demands imposed either by oneself or by others that are considered burdensome to students. Psychological Stress: The Lazarus Theory and Resource Theories of Stress: A Bridge between Systemic and Cognitive Viewpoints interactional as a highly relevant theory that supports the proposed conceptual model.

Based on the results of the research and the phenomena described above, the following hypotheses are:

- H1: E-learning has a significant effect on self-efficacy;

- H2: Learning motivation has a significant effect on self-efficacy;

- H3: E-learning has a significant effect on academic stress;

- H4: Learning motivation has a significant effect on academic stress;

- H5: Self-efficacy has a significant effect on academic stress;

- H6: E-learning has a significant effect on academic stress through self-efficacy;

- H7: Learning motivation has a significant effect on academic stress through selfefficacy.

\section{METHODS OF RESEARCH}

The population taken is Junior High School at one of the Junior High School in South Sumatra. Students are divided into three parts; class VII, class VII and class IX, but only 280 students were obtained from 946 students. The data were collected using a questionnaire on a Likert scale with 65 statements. The questionnaire was created and designed in Google Form format that allowed it to be distributed online to the respondents due to the COVID-19 pandemic. This research uses descriptive and quantitative analysis. The descriptive analysis serves to describe the frequency distribution of respondents' answers to variables. Quantitative analysis uses Structural Equation Modeling (SEM) from the Amos-23 software.

\section{RESULTS OF STUDY}

The evaluation of the model is done by looking at the value of the outer loading of each indicator with the provisions of the loading factor (Estimate) above 0.5. Based on table 1, it shows that the validity test on the variables of E-learning, learning motivation, self-efficacy and academic stress is known to all items with the loading factor value (Estimate) above 0.5.

Reliability is a measure of the internal consistency of the indicators of a construct variable that shows the degree to which each indicator indicates a general formation variable. There are 2 reliability tests, namely Composite (Construct) reliability and Variance 
RJOAS, 10(118), October 2021

extracted. The cut off value of Construct reliability is at least 0.70 while the Variance extracted is at least 0.50 .

Table 1 - Construct Validity test results or CFA Test

\begin{tabular}{|c|c|c|c|}
\hline Variable & Item & Score Loading Factor & Loading Factor Value Limit \\
\hline \multirow{20}{*}{ E-learning (W) } & Item1 & 0,824 & 0,5 \\
\hline & Item2 & 0,724 & 0,5 \\
\hline & Item3 & 0,667 & 0,5 \\
\hline & Item4 & 0,800 & 0,5 \\
\hline & Item5 & 0,720 & 0,5 \\
\hline & Item6 & 0,743 & 0,5 \\
\hline & Item7 & 0,796 & 0,5 \\
\hline & Item8 & 0,848 & 0,5 \\
\hline & Item9 & 0,787 & 0,5 \\
\hline & Item10 & 0,836 & 0,5 \\
\hline & Item11 & 0,810 & 0,5 \\
\hline & Item12 & 0,790 & 0,5 \\
\hline & Item13 & 0,762 & 0,5 \\
\hline & Item14 & 0,793 & 0,5 \\
\hline & Item15 & 0,645 & 0,5 \\
\hline & Item16 & 0,831 & 0,5 \\
\hline & Item17 & 0,748 & 0,5 \\
\hline & Item18 & 0,760 & 0,5 \\
\hline & Item19 & 0,795 & 0,5 \\
\hline & Item20 & 0,829 & 0,5 \\
\hline \multirow{11}{*}{ Motivation to learn $(\mathrm{X})$} & Item1 & 0,843 & 0,5 \\
\hline & Item2 & 0,874 & 0,5 \\
\hline & Item3 & 0,823 & 0,5 \\
\hline & Item4 & 0,807 & 0,5 \\
\hline & Item5 & 0,877 & 0,5 \\
\hline & Item6 & 0,859 & 0,5 \\
\hline & Item7 & 0,830 & 0,5 \\
\hline & Item8 & 0,890 & 0,5 \\
\hline & Item9 & 0,866 & 0,5 \\
\hline & Item10 & 0,820 & 0,5 \\
\hline & Item11 & 0,744 & 0,5 \\
\hline \multirow{16}{*}{ Self-efficacy $(Y)$} & Item1 & 0,724 & 0,5 \\
\hline & Item2 & 0,794 & 0,5 \\
\hline & Item3 & 0,795 & 0,5 \\
\hline & Item4 & 0,621 & 0,5 \\
\hline & Item5 & 0,863 & 0,5 \\
\hline & Item6 & 0,760 & 0,5 \\
\hline & Item7 & 0,884 & 0,5 \\
\hline & Item8 & 0,843 & 0,5 \\
\hline & Item9 & 0,824 & 0,5 \\
\hline & Item10 & 0,840 & 0,5 \\
\hline & Item11 & 0,769 & 0,5 \\
\hline & Item12 & 0,784 & 0,5 \\
\hline & Item13 & 0,829 & 0,5 \\
\hline & Item14 & 0,851 & 0,5 \\
\hline & Item15 & 0,846 & 0,5 \\
\hline & Item16 & 0,802 & 0,5 \\
\hline \multirow{18}{*}{ Academic stress (Z) } & Item1 & 0,760 & 0,5 \\
\hline & Item2 & 0,820 & 0,5 \\
\hline & Item3 & 0,807 & 0,5 \\
\hline & Item4 & 0,751 & 0,5 \\
\hline & Item5 & 0,811 & 0,5 \\
\hline & Item6 & 0,821 & 0,5 \\
\hline & Item7 & 0,736 & 0,5 \\
\hline & Item8 & 0,773 & 0,5 \\
\hline & Item9 & 0,758 & 0,5 \\
\hline & Item10 & 0,774 & 0,5 \\
\hline & Item11 & 0,734 & 0,5 \\
\hline & Item12 & 0,750 & 0,5 \\
\hline & Item13 & 0,766 & 0,5 \\
\hline & Item14 & 0,693 & 0,5 \\
\hline & Item15 & 0,717 & 0,5 \\
\hline & Item16 & 0,742 & 0,5 \\
\hline & Item17 & 0,745 & 0,5 \\
\hline & Item18 & 0,727 & 0,5 \\
\hline
\end{tabular}


Table 2 - Construct Reliability and Variance Extracted Test Results

\begin{tabular}{llll}
\hline Variable & Construct Reliability & Variance Extracted & Decision \\
\hline E-learning (W) & 0,969 & 0,608 & Reliable \\
Motivation to learn (X) & 0,964 & 0,706 & Reliable \\
Self-efficacy (Y) & 0,967 & 0,623 & Reliable \\
\hline Academic stress (Z) & 0,961 & 0,579 & Reliable \\
\hline
\end{tabular}

Based on table 2 above, it can be seen that the Construct reliability values of the four variables are all more than 0.70 and the Variance extracted value to the four variables is more than 0.50 so it can be concluded that the four variables are reliable.

The theoretical model that has been built in the first stage will be described in a SEM model diagram which will make it easier to see the causal relationships that you want to test. In this diagram, the relationships between constructs will be represented by arrows.

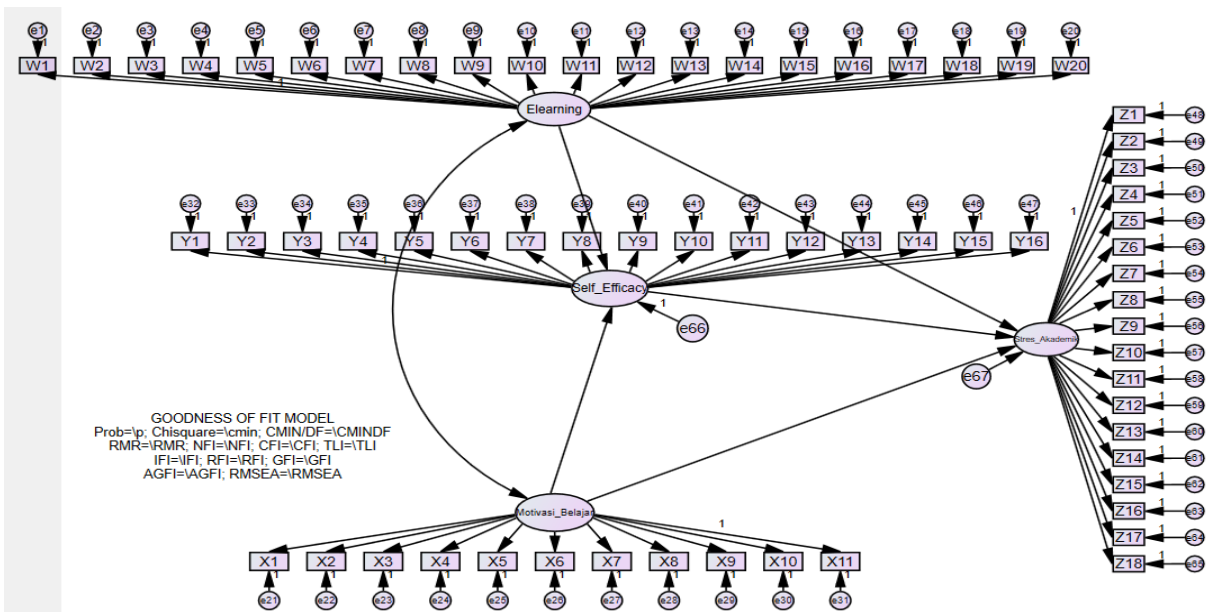

Figure 1 - Model Structural

Goodness of fit can be interpreted that the empirical data is suitable or in accordance with the model (there is no difference between the model and the data so that the model can be said to be fit). At this stage, testing is carried out on the suitability of the model against various criteria. The following table of criteria for assessment of Goodness of fit and the results:

Table 3 - Criteria and results of the Goodness of fit test

\begin{tabular}{llll}
\hline Goodness of Fit & Cut off value & Value & Result \\
\hline Probability Chi Square & $\geq 0,05$ & 0,000 & Bad Fit \\
CMIN/DF & $\leq 2,00$ & 1,435 & Good Fit \\
GFI & $\geq 0,90$ & 0,763 & Bad Fit \\
AGFI & $\geq 0,90$ & 0,747 & Bad Fit \\
CFI & $\geq 0,90$ & 0,944 & Good Fit \\
TLI & $\geq 0,90$ & 0,944 & Good Fit \\
NFI & $\geq 0,90$ & 0,837 & Marginal Fit \\
IFI & $\geq 0,90$ & 0,944 & Good Fit \\
RMSEA & $\leq 0,08$ & 0,040 & Good Fit \\
\hline RMR & $\leq 0,05$ & 0,062 & Marginal Fit \\
\hline
\end{tabular}

Overall Goodness of fit can be assessed based on at least 5 criteria. Based on the results of the output of table 4.7 above, it can be seen that the indicator value has met the Good fit of at least 5 indicators so that the overall model can be said to be fit because it has met the Good fit.

Hypothesis testing can be done through the bootstrap process and T-Statistic parameter testing, which is useful for predicting and knowing the relationship between variables. The limit value for hypothesis testing, namely T-Statistic Factor Loadings is greater than the critical value (>1.96), which can be seen in the following table: 
Table 4 - The Effect of the Variables of the Bootstrap Regression Weights Method

\begin{tabular}{lllllll}
\hline Parameter & & & Estimate & Lower & Upper & P \\
\hline Self_Efficacy & $<---$ & Elearning & .215 & .110 & .341 & .002 \\
Self_Efficacy & $<---$ & Learning_Motivation & .261 & .156 & .383 & .005 \\
Academic_stress & $<---$ & Self_Efficacy & -.432 & -.572 & -.326 & .003 \\
Academic_stress & $<---$ & Elearning & .057 & -.041 & .169 & .275 \\
Academic_stress & $<---$ & Learning_Motivation & -.314 & -.432 & -.225 & .002 \\
\hline
\end{tabular}

The mediation test of this research was carried out using the Calculation for The Sobel Test: An Interactive Calculation Tool for Mediation Test from Kristopher J. Peacher and Geoffrey J. Leonardelli by entering the coefficients a, b, Sa, and Sb.

Here are the results of the Sobel test:

1. The results of the Sobel test the effect of e-learning on academic stress through selfefficacy:

\begin{tabular}{|c|c|c|c|c|}
\hline \multicolumn{5}{|c|}{$\begin{array}{l}\text { To conduct the Sobel test } \\
\text { Details can be found in Baron and Kenny (1986), Sobel (1982), Goodman (1960), and Ma } \\
\text { Warsi, and Dwyer (1995). Insert the } a, b, s_{a} \text {, and } s_{b} \text { into the cells below and this program } \\
\text { calculate the critical ratio as a test of whether the indirect effect of the IV on the DV via th } \\
\text { mediator is significantly different from zero. }\end{array}$} \\
\hline Input: & & Test statistic: & Std. Error: & $p$-value: \\
\hline a 0.215 & Sobel test: & -3.12932884 & 0.02968049 & 0.00175206 \\
\hline$b-0.432$ & Aroian test: & -3.0971143 & 0.02998921 & 0.00195415 \\
\hline$s_{a} 0.058$ & Goodman test: & -3.16256998 & 0.02936852 & 0.00156383 \\
\hline$s_{\mathrm{b}} 0.074$ & Reset all & & Calculate & \\
\hline
\end{tabular}

Figure 2 - The results of the Sobel Test the effect of e-learning on academic stress through selfefficacy

The results of the Sobel test above can be seen that there is a significant effect of the mediating variable. This is indicated by the Sobel Test Statistic value (t-value) of -3.129 with a $p$ value of 0.002 which fulfills the requirements because it is smaller than 0.05 . So it can be concluded that E-learning has an effect on academic stress through self-efficacy during the Covid-19 pandemic.

2. The results of the Sobel test the effect of learning motivation on academic stress through self-efficacy:

\begin{tabular}{|c|c|c|c|c|}
\hline \multicolumn{5}{|c|}{$\begin{array}{l}\text { Details can be found in Baron and Kenny }(1986) \text {, Sobel (1982), Goodman }(1960) \text {, and Ma } \\
\text { Warsi, and Dwyer }(1995) \text {. Insert the } a, b, S_{a} \text {, and } s_{b} \text { into the cells below and this progran } \\
\text { calculate the critical ratio as a test of whether the indirect effect of the IV on the DV via t } \\
\text { mediator is significantly different from zero. }\end{array}$} \\
\hline Input: & & Test statistic: & Std. Error: & $p$-value: \\
\hline a 0.261 & Sobel test: & -3.45103016 & 0.03267198 & 0.00055845 \\
\hline$b \longdiv { - 0 . 4 3 2 }$ & Aroian test: & -3.41855681 & 0.03298234 & 0.00062954 \\
\hline$s_{\mathrm{a}} 0.061$ & Goodman test: & -3.48444685 & 0.03235865 & 0.00049316 \\
\hline$s _ { \mathrm { b } } \longdiv { 0 . 0 7 4 }$ & Reset all & & Calculate & \\
\hline
\end{tabular}

Figure 3 - The results of the Sobel Test the effect of learning motivation on academic stress through self-efficacy

Based on the results of the Sobel test above, it can be seen that there is a significant effect of the mediating variable. This is indicated by the Sobel Test Statistic value (t-value) of -3.451 with a $p$ value of 0.001 which fulfills the requirements because it is smaller than 0.05 . So it can be concluded that learning motivation has an effect on academic stress through self-efficacy during the Covid-19 pandemic. 


\section{DISCUSSION OF RESULTS}

Based on the results of the study, it is known that E-learning has an effect on selfefficacy during the Covid-19 pandemic. This is because the probability value is less than 0.05 $(0.002<0.05)$. The effect is positive because the regression coefficient (estimate) is positive, meaning that the increasing e-learning will increase self-efficacy. Thus the first hypothesis which states "E-learning has an effect on self-efficacy during the Covid-19 pandemic" is proven and can be declared accepted. The results of this study are in line with the results of research conducted by Meilati (2018) where the results of the study show that there is a significant positive relationship between online e-learning and self-efficacy.

Based on the results of the study, it is known that learning motivation has an effect on self-efficacy during the Covid-19 pandemic. This is because the probability value is less than $0.05(0.005<0.05)$. The effect is positive because the value of the regression coefficient (estimate) is positive, meaning that the higher the motivation to learn, the higher the selfefficacy. Thus the second hypothesis which states "Learning motivation affects self-efficacy during the Covid-19 pandemic" is proven and can be declared accepted. The results of this study are in line with the results of research conducted by Monika et., al (2017) where the results of the study show a positive relationship between learning motivation and selfefficacy.

Based on the results of the study, it is known that E-learning has no effect on academic stress during the Covid-19 pandemic. This is because the probability value is greater than $0.05(0.275>0.05)$. Thus the third hypothesis which states "E-learning has an effect on academic stress during the Covid-19 pandemic" is not proven and can be declared unacceptable. The results of this study are not in line with the results of research conducted by Allan and Lawless (2003) where in their research that online e-learning has a positive effect on academic stress.

Based on the results of the study, it is known that learning motivation has an effect on academic stress during the Covid-19 pandemic. This is because the probability value is less than $0.05(0.002<0.05)$. The effect is negative because the regression coefficient (estimate) is negative, meaning that the higher the motivation to learn, the lower the academic stress. Thus the fourth hypothesis which states "Learning motivation affects academic stress during the Covid-19 pandemic" is proven and can be declared accepted. The results of this study are in line with the results of research conducted by Seto et al., (2020) in their research revealing that learning motivation has a positive effect on academic stress.

Based on the results of the study, it is known that self-efficacy affects academic stress during the Covid-19 pandemic. This is because the probability value is less than $0.05(0.003$ $<0.05$ ). The effect is negative because the regression coefficient (estimate) is negative, meaning that the higher self-efficacy, the lower academic stress. Thus the fifth hypothesis which states "Self-efficacy affects academic stress during the Covid-19 pandemic" is proven and can be declared accepted. The results of this study are in line with the results of research conducted by (Cao et al., 2020) the results of the analysis show that there is a positive relationship between self-efficacy related to symptoms of academic stress.

Based on the results of the study, it is known that E-learning has an effect on academic stress through self-efficacy during the Covid-19 pandemic. This can be seen from the test of the effect of the mediating variable according to the criteria of Kenny et al., 1998 in Larsman, 2006 and MacKinnon, 2008, which found that the e-learning variable had a significant effect on self-efficacy, and the self-efficacy variable had a significant effect on academic stress, so that self efficacy as a mediator variable. Also based on the Sobel test, the $p$ value of 0.002 is less than 0.05 so that there is a significant effect of the mediating variable. Thus the sixth hypothesis which states "E-learning affects academic stress through self-efficacy during the Covid-19 pandemic" is proven and can be declared accepted.

Based on the results of the study, it is known that learning motivation has an effect on academic stress through self-efficacy during the Covid-19 pandemic. This can be seen from the test of the effect of the mediating variable according to the criteria of Kenny et al., 1998 in Larsman., 2006 and MacKinnon, 2008, which found that the learning motivation variable had 
a significant effect on self-efficacy, and the self-efficacy variable had a significant effect on academic stress. self-efficacy as a mediator variable. Also based on the Sobel test, the $p$ value of 0.001 is less than 0.05 so that there is a significant effect of the mediating variable. Thus the seventh hypothesis which states "Learning motivation affects academic stress through self-efficacy during the Covid-19 pandemic" is proven and can be declared accepted. The results of this study are in line with the results of research conducted by Chang et al., (2014) which showed a positive relationship related to learning motivation, self-efficacy and e-learning using social cognitive theory.

\section{CONCLUSION}

From the results of the data analysis above, it can be concluded as follows: E-learning has an effect on self-efficacy, meaning that the more e-learning increases, the higher selfefficacy. Learning motivation has an effect on self-efficacy during the Covid-19 pandemic, meaning that the increased motivation to learn will increase self-efficacy. E-learning has no effect on academic stress during the Covid-19 pandemic. Learning motivation has an effect on academic stress during the Covid-19 pandemic, meaning that the increased motivation to learn will reduce academic stress. Self-efficacy has an effect on academic stress during the Covid-19 pandemic, meaning that the higher self-efficacy, the lower academic stress. Elearning affects academic stress through self-efficacy during the Covid-19 pandemic. Learning motivation affects academic stress through self-efficacy during the Covid-19 pandemic

\section{REFERENCES}

1. Allan, J., \& Lawless, N. (2003). Stress Caused By On-Line Collaboration In E-learning: A Developing Model. Education + Training, 45(8), 564-572. https://doi.org/10.1108/00400910310508955.

2. Bandura, Albert. (1994). Self Efficacy. In V.S. Ramachaudran (Ed.), Encyclopedia Of Human Behavior (Vol. 4, Pp. 71-81). New York: Academic Press.

3. Barseli, M., Ahmad, R., \& Ifdil, I. (2018). Hubungan Stres Akademik Siswa Dengan Hasil Belajar.Jurnal Educatio: Jurnal Pendidikan Indonesia, 4(1), 40-47.

4. Cao, W., Fang, Z., Hou, G., Han, M., Xu, X., Dong, J., \& Zheng, J. (2020). The psychological impact of the COVID-19 epidemic on college students in China. Psychiatry Research, 287(March), 112934. https://doi.org/10.1016/j.psychres.2020.112934.

5. Chang, C. S., Liu, E. Z. F., Sung, H. Y., Lin, C. H., Chen, N. S., \& Cheng, S. S. (2014). Effects Of Online College Student's Internet Self-Efficacy On Learning Motivation And Performance. Innovations In Education And Teaching International, 51(4), 366-377. https://doi.org/10.1080/14703297.2013.77142.

6. Chang, Y. Y. C., \& Chiou, W. Bin. (2017). Prior self-efficacy interacts with experiential valence to influence self-efficacy among engineering students: An experimental study. Eurasia Journal of Mathematics, Science and Technology Education, 13 (3), 589-600. https://doi.org/10.12973/eurasia.2017.00634a.

7. Dada, J. O., Babatunde, S. O., \& Adeleye, R. O. (2019). Assessment Of Academic Stress And Coping Strategies Among Built Environment Undergraduate Students In Nigerian Higher Education. Journal Of Applied Research In Higher Education, 11(3), 367-378. https://doi.org/10.1108/jarhe-06-2018-0100.

8. Darin E. Hartley, Selling E-learning, American Society For Training And Development, 2001.

9. Donovan, M. S., Donovan, M. S., Bransford, J. D., \& Bransford, J. D. (1999). How People Learn: Bridging Research And Practice. In National Academy Of Sciences (Issue January 1999). http://www.nap.edu/catalog/9457.html.

10. Gikas, J., \& Grant, M. M. (2013). Mobile Computing Devices In Higher Education: Student Perspectives On Learning With Cellphones, Smartphones \& Social Media. The 
$\begin{array}{llll}\text { Internet Hnd Higher } \quad \text { Education, } & \text { 19-26. }\end{array}$ https://doi.org/https://doi.org/10.1016/j.iheduc.2013.06.002.

11. Hamzah B. Uno. (2017). Teori Motivasi Dan Pengukurannya. Bumi Aksara.

12. Hasan, N., \& Bao, Y. (2020). Impact Of "E-learning Crack-Up" Perception On Psychological Distress Among College Students During Covid-19 Pandemic: A Mediating Role Of "Fear Of Academic Year Loss." Children And YouthServices Review, 118(July), 105355. https://doi.org/10.1016/j.childyouth.2020.105355.

13. Lazarus, R.S. and Folkman, S. (1984), Stress, Appraisal, and Coping, Springer, New York, NY.

14. L. Petrides, "Web-Based Technologies For Distributed (Or Distance) Learning: Creating Learningcentered Educational Experiences In The Higher Education Classroom," Int. J. Instr. Media, Vol. 29, Pp. 69-77, Jan. 2002.

15. Matheny, Kenneth B., dkk. (1993). Stress in School-Aged Children and Youth. Educational Psychologhy Review, Vol. 5, School-Related Health and Safety. Part II, pp. $\begin{array}{llll}\text { 109-134. } & \text { Springer. } & \text { Diunduhpada } & 14 / 01 / 2015\end{array}$ darihttp://www.jstor.org/stable/23359233.

16. McClelland, D.C. 1987. Human Motivation. New York: The Press Syndicate of The University of Chambridge.

17. Meiliati, R., Darwis, M., \& Asdar. (2018). Pengaruh Motivasi Belajar, Self Efficacy, Dan Self Regulated Learning Terhadap Hasil Belajar Matematika. Issues In Mathematics Education, 2(1), 83-91.

18. Mödritscher, F. (2006). E-learning Theories In Practice: A Comparison Of Three. Journal Of Universal Science And Technology Of Learning (JUSTL), 0(0), 3-18. http://www.justl.org/justl_0_0/elearning_theories_in_practice.

19. Monika, M., \& Adman, A. (2017). Peran Efikasi Diri Dan Motivasi Belajar Dalam Meningkatkan Hasil Belajar Siswa Sekolah Menengah Kejuruan. Jurnal Pendidikan Manajemen Perkantoran, 2(2), 109. https://doi.org/10.17509/jpm.v2i2.8111.

20. Oon, A.N. (2007). Handling Study Stress. Jakarta: Alex Media Komputindo. Sarafino, E. P. 2006. Health Psychology (5nd. Ed). New York. John Wiley And Sons.

21. Prayogi, R., Suryatna, U., \& Kusumadinata, A. A. (2017). Hubungan Komunikasi Pembelajaran Sistem E-learning Dengan Motivasi Belajar Siswa (Kasus Pada Smk Wikrama Kota Bogor). Jurnal Komunikatio, 1(2), 99-113. https://doi.org/10.30997/jk.v1i2.174.

22. Rimbarizki, R. (2017). Penerapan Pembelajaran Daring Kombinasi Dalam Meningkatkan Motivasi Belajar Peserta Didik Paket C Vokasi Di Pusat Kegiatan Belajar Masyarakat (Pkbm) Pioneer Karanganyar. J+Plus Unesa, 6(2), 1-12.

23. Sarafino, E. P. 2006. Health Psychology (5nd. Ed). New York. John Wiley And Sons. 2 Tatan, Z. M. 2012. "Analisis Prokrastinasi Tugas Akhir Atau Skripsi". Prosiding. ISBN : 978-979-16353-8- 7.

24. Sarita, S. (2015). Academic Stress Among Students : Role And Responsibilities of Parents. International Journal Of Applied Research, 1 (10), 385-388.

25. Santrock JW. Psikologi Pendidikan. Edisi Kedua. Jakarta: Prenada Media Group; 2007.2.

26. Seto, S. B., Wondo, M. T. S., \& Mei, M. F. (2020). Hubungan Motivasi Terhadap Tingkat Stress Mahasiswa Dalam Menulis Tugas Akhir (Skripsi). Jurnal Basicedu, 4(3), 733-739. https://doi.org/10.31004/basicedu.v4i3.431.

27. Shadi, M., Peyman, N., Taghipour, A., \& Tehrani, H. (2018). Predictors Of The Academic Stress And Its Determinants Among Students Based On The Theory Of Planned Behavior. Fundamentals Of Mental Health, 20 (1), 87-98.

28. Utami, S., Rufaidah, A., \& Nisa, A. (2020). Kontribusi Self-Efficacy Terhadap Stres Akademik Mahasiswa Selama Pandemi Covid-19 Periode April-Mei 2020. Teraputik: Jurnal Bimbingan Dan Konseling, 4(1), 20-27. https://doi.org/10.26539/teraputik.41294.

29. Wloskowski, Raymond Dan Judith Jaynes. Hasrat Untuk Belajar. Yogyakarta: Pustaka Pelajar, 2004.

30. Wulandari, B., \& Surjono, H. D. (2013). Pengaruh Problem-Based Learning Terhadap Hasil Belajar Ditinjau Dari Motivasi Belajar Plc Di Smk. Jurnal Pendidikan Vokasi, 3(2), 
178-191. https://doi.org/10.21831/jpv.v3i2.1600.

31. Zega, Y., Tetap, D., Nias, Y., \& Gunungsitoli, I. (2020). Hubungan Self Efficacy Terhadap Motivasi Belajar Dalam Pembelajaran Matematika. Didaktik, 14(1),24102416. https://ojs.ikipgunungsitoli.ac.id/index.php/dk/article/view/69.

32. Zhang, Wei, and Yanchun Zhu. "A New E-learning Model Based on Elastic Cloud Computing for Distance Education." Eurasia Journal of Mathematics, Science and Technology Education 13, no. 12 (2017): 8393- 8403. https://doi.org/10.12973/ejmste/80800.

33. Zimmerman, B. (1990). Student Differences in Self-Regulated Learning: Relating Grade, And Giftedness to Self Efficacy and Strategy Use. Journal Of Educational Psychology, 83(1), 51-59. 